\title{
PLAYING TO THE PUBLIC, PLAYING WITH OPINION: LATIN AND VERNACULAR DUTCH HISTORY DRAMA BY HEINSIUS AND DUYM
}

\author{
Juliette Groenland
}

\section{INTRODUCTION}

A young and ambitious humanist scholar at Leiden University, Daniel Heinsius, made his name by composing a Senecan tragedy about a shocking event of consequence that was still fresh in Dutch memory: the murder of Prince William of Orange in July 1584 by the Catholic Balthasar Gerards, after King Philip II of Spain had placed a large reward on the head of the leader of the Dutch Revolt. ${ }^{1}$ Heinsius's Auriacus sive Libertas saucia ('William of Orange or Wounded Liberty', 1602) set the trend for a whole series of 'national' history dramas, ${ }^{2}$ not only in Neo-Latin but also in the vernacular, leading up to canonized exponents like Geeraerdt van Velsen (1613) and Baeto, of Oorsprong der Hollanderen ('Baeto or the Origin of the People of Holland', 1617), both by Pieter Corneliszoon Hooft, and Joost van den Vondel's Gysbreght van Aemstel (1637). The murder of William of Orange would be the subject of history plays with topical political messages for centuries to come. ${ }^{3}$ The illustrious line of vernacular plays is headed by Het moordadich stuck van Balthasar Gerards, begaen aen de doorluchtighen Prince van Oraignen. 1584 (The Murder of the Illustrious Prince of Orange Committed by Balthasar Gerards in 1584, 1606). The author,

\footnotetext{
1 This paper was written within the scope of Bloemendal's Vidi-project Latin and Vernacular Cultures: Theatre and Public Opinion in the Netherlands (ca. 1510-1625), funded by the Dutch Organisation for Scientific Research (NWO).

${ }^{2}$ I.e. history dramas about the past of the patria, a word which could be applied to a town as well as a larger geographical unity. For the concept patria within the 'Auriacus sive Libertas saucia' see Jan Bloemendal, 'Rond de Vader des Vaderlands'.

${ }^{3}$ Duits, Van Bartholomeusnacht tot Bataafse opstand, pp. 94-153 analyzes the play Wilhem of gequetste vryheyt ('William or wounded liberty', 1662) by Lambert van den Bosch; Orange plays in the 18th, 19th and early 20th centuries are listed in: Duym, Het moordadich stuck van Balthasar Gerards, ed. Serrarens and Wijngaards, p. 8.
} 
the rhetorician and war veteran Jacob Duym, presented his play in the preface to the reader as a direct adaptation of Heinsius's Auriacus. Heinsius sanctions this claim in a liminal poem, stating that Duym has thereby made the Neo-Latin play accessible to a Dutch-speaking audience.

At first sight there is a world of difference between the two Orange plays. Whereas Heinsius wrote an unbiased ancient tragedy based on topical subject matter, Duym's rhetorician drama shows clear political bias. Given the paratextual claims, scholars were struck by the liberties Duym had taken in his adaptation. Belittling the statements of both Duym and Heinsius, the twentieth-century editors of Duym's play accused the rhetorician of veiling the intended political impact of his composition in his preface 'To the reader' ${ }^{4}$ Heinsius's laudatory poem on the other hand was explained as the naive reaction of an egocentric bookish humanist. ${ }^{5}$ In their opinion, in the play itself Duym managed to get his political message across to the man in the street, while Heinsius cast an essentially broadly based political view in an ancient mould that was deemed to have 'alienated $99 \%$ of his fellow citizens' ${ }^{6}$

Starting from the coherence between the two dramas to which the authors themselves attested, this paper explores the extent to which the heightened topicality of Duym's play could be explained as the outcome of the process of translating or (as we would be inclined to call it) adapting the drama for another audience. In order to be effective, the topical political outlook of a drama requires a close-knit tie between message and audience. Could a change in the form and mode of expression at least partly have been dictated by a change in the social and institutional setting, and the literary tradition and conventions at play? In order to substantiate this hypothesis and thus both Duym's and Heinsius's claim, it will be crucial to differentiate between the various audiences and the corresponding language and literary traditions for which the plays were intended. Was the enhanced topicality in Duym's play suggested by the transposition from the code of ancient tragedy, which had been suitable for Heinsius's intended

\footnotetext{
${ }^{4}$ Duym, Het moordadich stuck, ed. Serrarens and Wijngaards, p. 14.

5 Ibidem, p. 52.

${ }^{6}$ Ibidem, p. 46.
} 
audience of fellow humanists, into the rhetorician's tradition familiar to Duym's target group? Furthermore, what can we gather about the function of the topical allusions in both dramas? Finally, on account of the extant source material, how can we assess the impact of both authors on the opinions of their public? Do the polarized judgments about the 'armchair scholar' Heinsius versus the 'people's man' Duym hold up under close scrutiny?

The relationship between the Orange plays of Heinsius and Duym raises crucial questions on the history of Dutch 'national' history drama in general. Together the plays represent a crucial stage in the emergence and development of the genre. The first Dutch national history dramas were composed in Neo-Latin. Although Heinsius was not the initiator, he certainly advocated the 'novel' genre, justifying himself in his preface to the Auriacus. Duym was the first (but not the only) vernacular dramatist directly inspired by Heinsius's Orange play, and demonstrated a tendency which would turn out to be very fruitful for the development of the genre: an ever-innovative topical treatment of the historic episode(s) at stake, adapted to the political situation of the moment. The insights gained about the connection between Heinsius and Duym throw light on the general interrelation between Neo-Latin and vernacular dramatists and their audiences. How far is this analysis in keeping with the common notion that the conservative and elitist Latin literary productions were pushed aside by competing vernacular counterparts produced more by and for the common people? Do Heinsius's and Duym's plays really represent conflicting opposites of a world in transition, or does their relationship point towards two coexisting and interfering cultural fields? Since topicality and public opinion play a key role in the way both dramatists try and interact with their audiences, what can this case study tell us about the relationship between early modern literature and public opinion in general? A short introduction to early Dutch history drama and the particular topical outlook of the genre will be followed by an analysis of the Orange plays by Heinsius and Duym: their allusions to contemporary politics on the one hand, the contexts in which they were composed and their (intended and actual) audiences on the other hand. Finally, I will discuss the particular relationship of the two plays: what do we learn about the relationship between Latin and vernacular authors and their audiences in general, and about the way the plays interact with the opinion or opinions of their audiences in particular? 


\section{EARLY DUTCH HISTORY DRAMA}

In the Dutch Republic as well as in other countries, history drama was revived and was brought to fruition in a period of heightened political awareness and intensified national consciousness. The decade after the defeat of the Armada bore witness to the majority of the great English history plays. ${ }^{7}$ In Spain Lope de Vega and his fellow playwrights produced historical dramas hailing Spain's destiny to rule the world. French history drama of the seventeenth century explored not the national but the Roman past for analogies with contemporary France; this might be explained by the authoritarian regime, ${ }^{8}$ the available national historical material, or the prevailing classicism..$^{9}$ In Germany, it would not be until the upsurge of nationalism in the age of Goethe that the German past would become a source of inspiration to playwrights.

Dutch history drama, like its Spanish and English counterparts, experienced its prime during the early seventeenth century. ${ }^{10}$ At the time of the Dutch Revolt, the subject matter of tragedies was no longer restricted to traditional biblical episodes. During the heated political and religious controversies, the playwrights explored highly disputed events from recent history. Previous research into English and Spanish Renaissance drama ${ }^{11}$ has established that the date of composition of a history play is a major determinant of both the nature of the historical representation and of the topical comment. Noak and Duits reached a similar conclusion concerning the Dutch Republic. However, their studies discuss plays in the vernacular only and cover a later period. ${ }^{12}$

Just as it has been argued that Spanish and English national history plays represent two separate traditions developing for the greater part independently, ${ }^{13}$ (northern) Dutch history drama seems to represent an independent line with its own dynamics as well. Outlining

${ }^{7}$ Lindenberger, Historical Drama, pp. 6-7.

${ }^{8}$ Ibidem, p. 7 points out that none of Shakespeare's English plays were written in the time of the Tudors; similarly, Henry VIII, stemming from the Stuart reign, is less political in content and method than the pre-Tudor plays.

${ }^{9}$ Loftis, Renaissance Drama in England and Spain, p. 6.

${ }^{10}$ See Groenland, 'The Deadly Earnest of History Plays'.

${ }_{11}$ Loftis, Renaissance Drama in England and Spain.

12 Duits, Van Bartholomeusnacht tot Bataafse opstand discusses plays from the period 1645-1663; a wider range, 1606-1673, is represented in Noak, Politische Auffassungen im niederländischen Drama des 17. Jahrhunderts.

${ }^{13}$ Loftis, Renaissance Drama in England and Spain, p. 4. 
the extant early specimens of the genre, from the period 1580-1625, representing the turbulent Dutch Republic in the making, the following dramas can be counted among the tradition:

(Panagius Salius (Toussaint du Sel), Nassovius (1589)) $)^{14}$

Caspar Casparius (Caspar Ens), Princeps Auriacus sive Libertas defensa (The Prince of Orange or Liberty Defended, 1598)

Daniel Heinsius, Auriacus sive Libertas saucia (1602)

Jacob Duym, Het moordadich stuck van Balthasar Gerards, begaen aen de doorluchtighen Prince van Oraignen (1606)

Gijsbrecht van Hogendorp, Treur-spel van de moordt (Tragedy of the Murder, 1616)

Pieter Corneliszoon Hooft, Geeraerdt van Velsen (1613) and Baeto, of Oorsprong der Hollanderen (Baeto or the Origin of the People of Holland, 1617)

Govert vander Eembd, Haerlems belegerings treur-blij-eynde-spel (1619) Jacobus Zevecotius (Jacques de Zevecote), Maria Stuarta / Maria Graeca (1623/1625), and Belegh van Leyden. Treurspel (Siege of Leiden. A Tragedy, $1626(1632))$.

This list of history dramas shows that Heinsius's Auriacus was preceded and inspired by an Orange play of the Delft Deputy Headmaster Caspar Ens, as the subtitle of Heinsius's play explicitly shows. ${ }^{15}$ Caspar Ens's Orange play, probably performed at the Latin school in Delft and published together with a political pamphlet, may have reached a considerable audience. ${ }^{16}$ Daniel Heinsius's Auriacus, however, became the trendsetter, extending its influence even to the history dramas by Hooft or Zevecotius's Maria Stuarta, treating contemporary issues under the cloak of more distant historical events.

Overall, the list reveals the manifold levels on which these history plays reflect different cultural, institutional and social fields: plays in

${ }^{14}$ The first Orange play originated in the Southern Low Countries and is a proSpanish portrayal of William of Orange as a tyrant. However, it seems Salius's drama remained unknown in the Dutch Republic. To this list other tragedies could be added, for instance Govert vander Eembd, Haerlems belegerings treur-blij-eynde-spel (1619), but I will restrict myself to treating the tragedies that belong to one single cluster.

${ }^{15}$ The title of Heinsius's Auriacus sive Libertas saucia not only shows the author's indebtedness to his predecessor, but articulates at the same time, according to the good humanist principle of imitatio et aemulatio, the different outlook of the two dramas. The message of Casparius's play was ultimately an optimistic one, whereas Heinsius, bent on composing a true 'tragic' tragedy, emphasized the damage that had been done to Liberty.

${ }^{16}$ For a modern edition with translation in Dutch see Ens, Princeps Auriacus, ed. Bloemendal and Steenbeek; for a discussion of the political purport of the play and its publication see Groenland, 'Toneel als pamflet?'. 
Neo-Latin as well as in the vernacular, conceived in humanist strongholds like the Latin school or the university as well as in the chambers of rhetoric and the newly built Amsterdam theatre. Nonetheless, the autonomous development of the genre within the Dutch Republic, cutting right across all these fields, supports the supposition that authors such as Duym and Heinsius, at least up to a certain point, worked in the same cultural domain. All the history dramas appeal somehow to the collective memory of the young Republic by reviving a traumatic episode in order to underpin and enforce the political and religious consciousness of its citizens.

\section{TOPICAL POLITICS AND INTENDED AUDIENCE}

Aristotle's famous definition of literature as an art of 'mimesis' (which was well-known to Heinsius), ${ }^{17}$ draws attention to the ambivalent nature of literature in general and of history drama in particular, situated midway between imaginative universals and particulars in the external world: ${ }^{18}$

What we have said already makes it further clear that a poet's object is not to tell what actually happened but what could and would happen either probably or inevitably. The difference between an historian and a poet is not that one writes in prose and the other in verse-indeed the writings of Herodotus could be put into verse and yet would still be a kind of history, whether written in metre or not. The real difference is this, that one tells what happened and the other what might happen. For this reason poetry is something more scientific and serious than history, because poetry tends to give general truths while history gives particular facts. $[\ldots]$

It is clear, then, from what we have said that the poet must be a 'maker' not of verses but of stories, since he is a poet in virtue of his 'representation,' and what he represents is action. Even supposing he represents what has actually happened, he is none the less a poet, for there is nothing to prevent some actual occurrences being the sort of thing that would probably or inevitably happen, and it is in virtue of that that he is their 'maker.'19

\footnotetext{
${ }^{17}$ Daniel Heinsius published his commentary on Aristotle, entitled De tragoediae constitutione, in 1611.

${ }^{18}$ Lindenberger, Historical Drama, p. x.

${ }_{19}$ Aristotle, Poetics 9.1-3; 9.9-10, transl. Hamilton Fyfe, pp. 35-37.
} 
Renaissance historiographers, basing their work on ancient models, were not only (nor even primarily) interested in historic particulars. They presented their public rather with a past that was 'universal' in the sense that present-day lessons could be conveyed: moral lessons, including-since politics were from the outset considered a part of ethics-political lessons. ${ }^{20}$ Classical Greek and Latin historiographies and tragedies-genres depicting the life of the high and mighty, and considered to teach philosophy by example-are interspersed with reflections on the arguments pro et contra different forms of government or the relationships between a ruler and his subjects. The political debates do not primarily have to be instigated by contemporary political issues. A discussion about the technical aspects of politics can also, or even simultaneously, be a matter of literary convention, a dialogue between the playwright and his sources.

However, when it comes to national history plays, authors often make full use of the opportunity to interact with their public and present their audience with topical political lessons. The production of national history dramas corresponded with a growing sense of patriotism within the Dutch Republic in the making. The portrayal of William of Orange as hero and martyr in the Orange plays served to build his image as a pater patriae, champion of the nation's liberty. Pieter Corneliszoon Hooft resorted to an earlier historic episode in his Geeraert van Velsen or even the Republic's dark mythological beginnings in his Baeto oft Oorsprong der Hollanderen, conceived as the Dutch Aeneid. In this play the mythological founding father Baeto is, like Virgil's Aeneas, urged to flee his native land and establish a future homeland for the Batavians in an uninhabited area between the Rhine, the Meuse and the Ocean. In a final scene interspersed with topical references, Baeto is granted the highest authority by Burgerhart, representative of the citizenry, with the approval of the soldiers and the religious leader Zegemond, acknowledging the supremacy of the State over the Church. Lifted upon his shield, Baeto swears an oath to govern henceforth in concordance with the noblest and best of citizens. Likewise, a civic humanist tendency instigated historiographies like Grotius's Liber de antiquitate reipublicae Bataviae (1610), legitimizing

${ }^{20}$ Cf. Aristotle's Politics (c. 340 B.C.), Cicero's De officiis (c. 45 B.C.), Erasmus's Institutio principis Christiani (1516), Lipsius's Politicorum sive civilis doctrinae libri $\operatorname{sex}(1589)$. 
the young Dutch Republic by stressing the nation's ancient tradition of independence, traced all the way back to Roman times, presenting the Batavian ancestors as equal confederates of the Roman empire. Grotius thus argued that the States had been in possession of the ultimate sovereignty since ancient Batavian times. Henceforth, if the sovereign appointed by the States does not govern and protect them properly, the States have the right to rise against him. ${ }^{21}$

Samuel Taylor Coleridge's thesis 'in order that a drama may be properly historical, it is necessary that it should be the history of the people to whom it is addressed ${ }^{22}$ touches the essence of national history plays. ${ }^{23}$ They need to represent history in such a way that it is recognized and/or picked up on by audiences as being 'their own' past. A telling illustration of this close tie between subject matter and audience is the captatio benevolentiae of Heinsius in his dedication of the Auriacus to the States of Holland and West Frisia:

Ego vero, illustrissimi Ordines, Tragoediam vobis offero meam; imo vestram: quod in ea meum est, trado vobis: quod vestrum est, ut gratum sit id quod offero, efficiet. Ita simul quod in reliquis Tragicis deplorari solet effugi, viamque mihi ad benevolentiam vestram praeparavi. ${ }^{24}$

I offer you, illustrious States, my tragedy, or rather yours: my part in it I hand over to you; your part in it will make sure that you like what I offer you. Thus I escape what is deplored in other tragedies, and pave my way to your benevolence.

Looking at the Dutch national history plays, the following tendencies apparently hold true: the more universal the content, the more familiar and politically pronounced the historic subject matter; the more distant the historic subject matter, the more topical (and thus more elaborately politically coloured) the content. Heinsius's Auriacus sive Libertas saucia ('William of Orange or Wounded Liberty') already shows its political message in the title; by contrast, the plot itself presents the downfall of a remarkably universal stoic hero, as will be discussed below. Conversely, when Hooft treats distant historical events, the topical political message is more fully elaborated throughout the

${ }^{21}$ See Van Gelderen, The Political Thought of The Dutch Revolt.

${ }_{22}$ Coleridge, The Literary Remains vol. 2, p. 142.

${ }_{23}$ Lindenberger, Historical Drama, pp. 6-8.

${ }^{24}$ Daniel Heinsius, Auriacus sive Libertas saucia, ed. Bloemendal, 1, p. 190. 
plot, and underlined by means that explicitly link the play's past with the public's present.

The close tie between a 'national' history play and its intended audience could provide the explanation to the question of why both authors claim that a play like Duym's Het moordadich stuck van Balthasar Gerards, begaen aen de doorluchtighen Prince van Oraignen (The Murder of the Illustrious Prince of Orange Committed by Balthasar Gerards), seemingly very different, is nevertheless an adaptation in the vernacular of Heinsius's Auriacus. Could the shifts in form and mode of the topical allusions have been dictated, at least in part, by a shift in the sociocultural field for which they were produced?

\section{Daniel Heinsius's Auriacus sive Libertas saucia (1602)}

Heinsius's decision to stage and publish the Auriacus in an attempt to establish his reputation as a scholar may be considered a daring enterprise, but was guaranteed to attract attention. At Leiden University, writing a play around the turn of the seventeenth century was not the safest and most modest career move. Since December 1595, theatrical performances were apparently suffering from a policy of determent. ${ }^{25}$ For all that, Heinsius and his friend Hugo Grotius, another rising star in Leiden, set out to secure a revival of ancient tragedy. Grotius wrote the biblical drama Adamus exul which was bound to please the Calvinist theologians. Heinsius took the clever decision to write a history drama commemorating and glorifying Prince William of Orange, the founding father of the University. ${ }^{26}$ As far as we know, Auriacus was the first play to appear on stage at the university after five years of an absence of drama performances-at least once, shortly after 25 January 1602, and perhaps even several times. ${ }^{27}$ Moreover, the debut was apparently lent additional lustre by the presence of the

${ }^{25}$ In 1595 decrees were issued stating that comedies or tragedies were only to be performed during holidays and with explicit permission of the rector magnificus and four assessores. In 1596, students proposing plays as part of a Bacchus celebration were told by the senate that performing tragedies or comedies was not in keeping with their dignity as members of the academy. Koppenol, Leids heelal, pp. 123-24.

${ }^{26}$ On the suggestion of William of Orange, Leiden University was founded by the States of Holland on 8 February 1575 as a reward for the town's brave resistance against the Spanish invaders, in order to serve as 'a staunch support and maintenance of the freedom and good lawful government of the country'.

${ }^{27}$ Heinsius, Auriacus sive Libertas saucia, ed. Bloemendal, 1, pp. 34-36. 
academic and political establishment, including one of the two sons of William (either Prince Maurits or Prince Frederic Henry), as Heinsius makes clear in his laudatory poem honouring the printed edition of Duym's Het moordadich Stuck from 1606:

In Balthasaris Gerardi execrandum facinus, a nobili viro Iacobo Duymio vernacula lingua conscriptum

Iberi scelus improbum dolusque,

Victori miserabilis Batavo,

Cum princeps populique patriaeque

Uno concidit impetitus ictu,

Nostro cum steterat prius cothurno,

Favit maxima Leida, favit ipsa

Totis plausibus annuens imago.

Favit Douza sui pater Lycei,

Favit maxima Caesaris propago,

Et Graiae columen Faber Camenae,

Et Grotius pia cura, Scriveriusque,

Et Graias Latiasque qui Camenas

Et Graias Latiasque amaret artes.

Muto caetera gens stetit theatro

Solis nescia gestibus doceri.

Vetat Duymius et vetans latere

Belgas protenus induit cothurno.

Belgae Belgia plausit, et 'quid', inquit,

'Rem decet populique patriaeque

Et patem populique patriaeque

Qui Belgiis periit, loqui Latinis?'

Stans pede in uno,

Daniel Heinsius ${ }^{28}$

On the loathsome crime of Balthasar Gerards, rendered by the nobleman Jacob Duym in the vernacular

When the scandalous crime and deceit of the Spaniard,

Dreadful for the victorious Batavian-

For the Prince of the people and the country

Was assaulted and struck down by one blow-,

Previously was staged in that tragedy of ours,

Leiden was highly pleased, even his spitting image $e^{29}$

was pleased, approving with warm applause.

${ }^{28}$ Duym, Het moordadich stuck, ed. Serrarens and Wijngaards, pp. 52-53.

${ }^{29}$ Apparently either Prince Maurits or Frederic Henry was present when the play was performed. 
Dousa, the father of his own University, ${ }^{30}$ was pleased.

The son of Caesar ${ }^{31}$ was highly pleased,

And Faber, ${ }^{32}$ pillar of the Greek Muse,

And gentle and thoughtful Grotius, and Scriverius, ${ }^{33}$

And all lovers of the Greek and Latin Muses,

And of the Greek and Latin arts.

The other people stood in a speechless theatre,

Not knowing how to understand mere gestures.

Duym resists, and resisting that it remained hidden,

He instantly dressed the Dutchman in the tragic boot.

The Dutch country applauded for the Dutch and said: 'Why

Does it befit an affair of the citizens and the country

And the father of the citizens and the country,

Who died for the Dutch, to speak for the Latins?'

In less than no time,

Daniel Heinsius.'

Heinsius stresses the different target groups of his Orange play and Duym's translation in the vernacular. Even so the play, meant for a humanist audience well-versed in Greek and Latin literature, was apparently also attended by people of more modest education, unable to decipher Latin, and thus, according to Heinsius, unable to understand the play merely on the basis of the body language of the actors. Heinsius, while stressing the success of his own play, gives Duym credit for suitably unlocking the play about the founding father of the Dutch nation for a Dutch-speaking audience.

The play not only enjoyed one or more performances at Leiden University, but was also published in a printed edition, issued with the support of all leading humanists of the academy, according to the abundant praise in a great variety of liminal poems. ${ }^{34}$ In the dedication of the play to the States of Holland and West Frisia, Heinsius makes an effort to stress the novelty of the genre: while the Greek and Roman genre of tragedy is the most dignified of all, Heinsius distances himself

${ }^{30}$ Janus Dousa was the first curator of the Leiden University.

${ }^{31}$ Josephus Justus Scaliger, the son of Julius Caesar Scaliger.

${ }^{32}$ Bonaventura Vulcanius, professor of Greek at Leiden University.

${ }_{33}$ The historian and poet Petrus Scriverius wrote a chronicle of Holland in the vernacular, Beschrijvinghe van Out Batavien, mitsgaders d'Afkomst ende historie der graven van Holland, Zeeland ende Vrieslandt (1612), as a follow-up to a history of the Counts of Holland by Jacob Duym. In 1616 he edited the Nederduitsche gedichten by Daniel Heinsius.

${ }^{34}$ Josephus Justus Scaliger, Hugo Grotius and Janus Dousa (among others) honoured the printed publication of Auriacus with laudatory poems. 
from the 'idle and foolish' stories of most ancient tragedies, derived from classical mythology. ${ }^{35}$ In Antiquity, tragedy was especially valued for the lessons it could provide in sapientia moralis civilisque ('moral and political wisdom'). Accordingly, Heinsius has found worthy subject matter in the recent history of Holland. ${ }^{36}$

The well-wrought tragedy is modelled on those attributed to Seneca, speaking louder in words than in action, full of ethical contemplations. As such, Heinsius's Auriacus is a didactic drama, in the tradition of the humanist school plays. Moreover, the moral lessons in the history play are in line with the important function attached to the study of history in the humanist school curriculum, which was considered to teach ethics by example. ${ }^{37}$ The Auriacus conveys a stoic message. Following Seneca, Heinsius makes William of Orange out to be a true stoic hero, facing his inevitable destiny with superhuman constancy and fortitude. ${ }^{38}$ Thus, in comparison with subsequent Orange plays, Auriacus is remarkably timeless.

However, the universal content does not prevent topicality from playing its part. In fact, the ancient outlook and the topical political message, reinforcing each other, must have been a very natural and effective combination to Heinsius and his humanist public. When Heinsius set out to imitate and emulate ancient tragedy in his own time and place, treating the trials and tribulations of the high and mighty, the combination of the 'royal' genre of tragedy with 'Orange, your leader' was an obvious choice, as he made clear in his dedication to the States of Holland and West Frisia. Conversely, the classical mould might be considered the most impressive way to bring home a proud patriotic message to his humanist audience, well-trained in the literary code of the ancients. Heinsius wrote his history play at a time that the Republic prospered and the princes of Orange scored

\footnotetext{
${ }^{35}$ As early as Roman times, tragedies about (near-)contemporary Roman history were written, the so-called fabulae praetextae. The pseudo-Senecan Octavia is the only extant complete ancient Latin history play. The first Renaissance humanist play, Ecerinis (1315) by Albertino Mussato, inspired by the discovery of a manuscript with Seneca's tragedies, is a history play in Senecan tradition. However, in the dedication of Auriacus Heinsius is referring to the mythological subgenre which was in his time and place most commonly understood as a synonym for ancient tragedy; ethical motives had prompted Dutch humanist educators since the beginning of the sixteenth century to resort to biblical tragedies in ancient fashion, but with a scriptural subject matter.

${ }^{36}$ Heinsius, Auriacus sive Libertas saucia, ed. Bloemendal, 1, p. 190.

${ }^{37}$ Groenland, 'Tijdloze geschiedenislessen'.

${ }^{38}$ Bloemendal, 'Willem van Oranje: Een Hercules op Leidse planken'.
} 
successes on the battlefield against the Spanish 'oppressor'. Heinsius target group, the academic community in Leiden, was certainly not led astray by the antiquated mould in which the contemporary lesson was cast. The terms of praise that the humanist scholar Josephus Justus Scaliger used to summarize the play's merits leave no doubt that Heinsius succeeded in bringing home to his audience a topical political message: 'Thanks to the lofty verses of Heinsius, the death that is a unique source of shame to you[, Spaniard], amounts for the Prince of Nassau to eternal life'. ${ }^{39}$

In this respect, a striking and significant last minute-change was made to the printed version of the play, right in the middle of the production process. After the text was printed, but before the leaves were bound, a scene of two pages was added..$^{40}$ Prince Maurits-William's son who had been only eighteen years old at the time of the murder but had developed another eighteen years later into the military leader of the Dutch Revolt-enters the scene and delivers a hopeful speech, promising the Dutch nation in despair that his father's death will be avenged. In the preface to the reader, who was sure to have acquired an adequate level of humanist learning, Heinsius made an effort to justify the insertion of this final monologue. Assuring the reader that it was not at his behest that Prince Maurits played a part in the play, Heinsius refers to 'persons of consequence'-presumably representatives from the university board or the government, which were to lend support to the play's performance-exerting pressure on him to pronounce his loyalty to the Stadtholder in a more straightforward fashion. ${ }^{41}$ Of course, Heinsius did not object to political propaganda as such. As noted above, like all humanists he was deeply convinced that literature should instil moral and political lessons in readers and spectators. Heinsius's objection was dictated by his profound knowledge of ancient poetics reflected in his Aristotle commentary De tragoedia constitutione (1611). He was convinced that a playwright following the ancient tradition had to keep the unity of time and place. ${ }^{42}$ Since

\footnotetext{
39 'Grandiloquis Heynsi numeris, quae dedecus una est / Mors tibi, Nassovio vita perennis erit'. Heinsius, Auriacus sive Libertas saucia, ed. Bloemendal, 1, pp. 208-09.

${ }_{40}$ The word Finis is printed after the original ending, the monologue of Libertas, and the new concluding monologue by Maurits is set in a different typography. Heinsius, Auriacus sive Libertas saucia, ed. Bloemendal, 1, p. 130.

${ }^{41}$ For this interpretation see Groenland, 'Predicting the Present'.

${ }^{42}$ Cf. Meter, De literaire theorieën van Daniël Heinsius, pp. 583, 586; Scaliger, Poetices libri septem, 3.96, ed. Deitz, 3, pp. 28.22-30.24.
} 
Maurits had not been present in Delft that fatal day, Heinsius could not give him a part in the play that represented the murder of his father William. Apparently by way of compromise, Heinsius did ultimately come up with a solution. He put the Prince on stage, but found a way to adhere to his poetical principles at the same time. In keeping with humanist tradition Prince Maurits became a deus ex machina, the divinity falling out of the sky at the end of an ancient play, proclaiming the subsequent course of events. ${ }^{43}$ The monologue not only made it into the printed edition of the play. In the preface to the reader, Heinsius added that he would only put the monologue in print when it had proven its worth during the performance. Thus from the last minute-revision in print we may well conclude that it received a warm welcome from the audience. ${ }^{44}$

Prince Maurits's final monologue ensured that the topical political message was not lost on any of the spectators, whatever the nature and level of their education. Moreover, in the penultimate scene-which had been the original end of the play-the audience had been confronted with utter despair and abandonment. They had been watching the ill-fated departure of both the assassinated William of Orange and the Liberty of the Republic from the stage, from 'the civilized world', and ultimately-reminiscent of a traumatic episode that was still fresh in their memory-from them. In the revised version, with the present leader appearing on stage as the heaven-sent saviour of the Republic, the sentiments aroused were directly released and steered into a definite political direction.

As Heinsius wanted to make clear in the preface to the reader, he had added Maurits's monologue not without demur. Ironically, following the lead of Auriacus, the insertion of a final prophecy, linking the play's past to the present of its public, became a popular device among Dutch playwrights. Vernacular playwrights like Duym, Van Hogendorp, Hooft and Vondel readily recognized the opportunity to stress the topical interest of their history play and reach out to their

${ }^{43}$ Aristotle, Poetica 1454 b2-5.

${ }^{44}$ Source material suggests that Heinsius composed his Auriacus in the autumn of 1601. The performance took place shortly after 25 January 1602 . The printed edition appeared before 8 May 1602. We may induce that the original version of Auriacus, without the final monologue by Prince Maurits, was already in print before the performance. After the extended closing scene had proved its success on stage, two pages were added before the leaves were bound. Cf. Heinsius, Auriacus sive Libertas saucia, ed. Bloemendal, 1, pp. 33-36. 
audiences. ${ }^{45}$ This manifold reception and the lasting fame of the prediction by the River Vecht in Hooft's Geeraerdt van Velsen (1613), or that of the Archangel Raphael in Vondel's Gysbrecht van Aemstel (1638), even raises the question of whether Heinsius's initiative to promote the history play would have met with the same success had he not granted Prince Maurits the last word in his Auriacus.

\section{JaCob Duym and his GHEDENCK-BOECK CONTAINING HET MOORDADICH STUCK (1606)}

'Of all authors that have played a significant part in the development from rhetorician to Renaissance drama, Jacob Duym has received least attention. The great playwrights have their own monographs by now, except for Duym, with no less than twelve plays one of the most productive writers of his generation. ${ }^{36}$ So proclaims Koppenol in a relatively recent first step to redirect attention to Duym. The last comprehensive study dedicated to the dramatist dates from more than a century ago. ${ }^{47}$

Born in Leuven of noble family, Jacob Duym obtained his university degree at the Faculty of Law. Initially he established himself as a lawyer and, after having been given various public duties, became one of the town's dignitaries. In 1576 he made a career change and joined the military, at first serving as a captain under Don John of Austria, Philip II's Governor-General of the Low Countries. However, in 1584 Duym resurfaced on the rebels' side, commanding infantry in defence of Fort Lillo near Antwerp against the Duke of Parma's troops. Resistance was futile: Parma had Antwerp firmly in his grasp and Duym was captured, on his own account on the battlefield, but according to a town historiographer on his country estate in the presence of his wife and children. After nearly two years of imprisonment Duym managed to buy himself out of the army following the Fall of Antwerp. Nevertheless, physically disabled for life, Duym escaped the war. Fleeing from

\footnotetext{
${ }^{45}$ For a discussion of the final prophecies in Duym's Moordadich Stuck, Van Hogendorp's Treur-spel van de moordt and Geeraerdt van Velsen and Baeto by Hooft, as well as their connection with Heinsius's Auriacus, see Groenland, 'Predicting the present.'

${ }^{46}$ Koppenol, 'Jacob Duym en de Leidse rederijkers'.

47 Poll, Over de tooneelspelen van den Leidschen rederijker Jacob Duym.
} 
the Spanish Low Countries, he arrived in Leiden in 1586. He remained a fervent supporter of the House of Orange.

An application for the staging of two plays to the town council of Leiden dating from 1588 is the first evidence of Duym's activities as a playwright. Two years later the municipality honoured a request by Flemish refugees to establish their own chamber of rhetoric, separate from the existing chamber 'De Witte Acoleyen'. Up to now it was assumed that Duym was attached to the Flemish chamber 'd'Orainge Lelie' right from the start, although his name is absent from the members' list of 1590. Koppenol, however, argues convincingly-on the basis of (among other things) the act of Duym's appointment in 1591 as Emperor of the chamber-that only then was Duym pushed forward as an external candidate by the town council. The municipality wanted to restore order after the church council had complained about de misbruycken die in eenige speelen zouden mogen zyn gepleecht ('malpractices that seemingly have been committed in some plays'). ${ }^{48}$ From 1592 until 1600, Duym's literary activities are well documented. 'D'Orainge Lelie' produced Duym's Spieghel der rechtvoordering ('The Mirror of Legal Claim', 1592), Spieghel der Eerbaerheyt ('The Mirror of Decency', 1595), Spieghel der liefde ('The Mirror of Love', 1596). Den spieghel der Getrouwicheyt ('The Mirror of Fidelity', 1600) and Den Spieghel des hoogmoets ('The Mirror of Pride', 1600). The last work is an adaptation of Seneca's Troades. In 1600 these five plays and Den Spieghel der Reynicheyt ('The Mirror of Chastity') were published in one volume: Duym's Spiegelboeck ('The Book of Mirrors').

Duym and his plays then seem to have disappeared from the scene of the Flemish chamber. Did Duym and 'd'Oraigne Lelie' sever relations? From then on Duym's publications show a thematic change and an expansion of his network. Compared to his Spiegelboeck, the liminal poetry in his Ghedenck-boeck of 1606, a collection of six new plays, is written by a greater number of humanists from Leiden University, members of the chamber of rhetoric 'De Witte Acoleyen' instead of 'd'Oraigne Lelie', and Carel van Mander from Haarlem and his circle. The six new plays in the Ghedenck-boeck ('The Book of Memory') represent near-contemporary episodes of the Dutch Revolt, recalling the atrocities committed by the Spaniards and the hardship endured by, and the achievements of, the Princes of Orange: the

\footnotetext{
${ }^{48}$ Koppenol, 'Jacob Duym en de Leidse rederijkers', p. 15.
} 
capture of Breda, the siege and relief of Leiden, the battle of Antwerp, and also, following Heinsius's Auriacus, the assassination of William the Silent.

The topical message of Duym's 'Book of Memory' as a whole is expressed in the aphoristic title of one of the plays: Een bewys dat beter is eenen goeden crijgh, dan eenen gheveynsden peys ('Proof That a Fair Battle Beats a Fake Peace'). Duym wanted to (re)confront his audience with all the hardship they suffered at the hands of a relentless and treacherous Spanish enemy. Het moordadich stuck neatly fitted in with the overall purpose of the book, since Duym looked to the Prince's sons to carry on the war in the name of their father. As Duym puts it in the dedication of Het moordadich Stuck to Frederick Henry: 'niet twijfelende uwe Excellentie soo 't alreede ghenoegh heft ghebleken, is bereyd om dese moord aen den Heere Prince voorsz begaen tot den uytersten te wreken, ende Spaingnaerden den rechten loon die sy wel hebben verdient te gheven' ('not doubting that your Excellency, for this became already sufficiently clear, is willing to avenge this murder inflicted on the aforementioned Prince to the extreme, and to give the Spaniards the just reward that serves them right').

Does the militant message of Duym's play justify the conclusion that Duym was 'representing the anti-peace movement at a critical moment in Dutch history, when Johan van Oldenbarnevelt began to advocate peace deliberately and openly" ${ }^{49}$ Can we even go as far as to infer that 'Duym was trying to influence the political decision-making process, by dedicating the 'Book of Memory' as a whole to Prince Maurice and, tellingly, Een bewys dat beter is eenen goeden crijgh, dan eenen gheveynsden peys to Johan van Oldenbarnevelt'?50 That is to say, are we to infer that Duym did articulate the allegedly bellicose vox populi, and dedicated his play to Oldenbarnevelt in the hope of convincing a supposed peace-loving leader? I am afraid that scholars, blinded by the later course of events, may, in this case, have jumped to conclusions too hastily.

From 1606 onwards the young Dutch Republic would be facing an increasing polarization between the military leader Prince Maurits and Grand Pensionary Johan van Oldenbarnevelt. In the course of that year negotiations started which would lead to the Twelve-Years'

${ }^{49}$ Wijngaards, 'De zgn. Oranjestukken en hun publiek', p. 127.

${ }^{50}$ Duits, Van Bartholomeusnacht tot Bataafse opstand, p. 100. 
Truce with Spain in 1609. However, the dedication of Het moordadich stuck is, like the dedications of all other five plays, dated 1 January 1606. The Ghedenck-boeck, with an imprint by H.L. van Haestens in Leiden in 1606 , was probably published shortly after. ${ }^{51}$ The six plays must have been in progress well before that time. While Oldenbarnevelt may privately have been pondering peace earlier, up until the autumn of 1606 the States, headed by the Grand Pensionary, categorically rejected every direct or indirect proposition of peace. ${ }^{52}$ The population was, however, feeling the full weight of the costs of a war which after almost four decades was losing its idealistic zeal and progress. The golden days of prosperity and military successes seemed to have passed, and support from former allies like England and France began to waver. ${ }^{53}$ It is likely that Duym's pro-war plays fought against certain popular sentiments while siding with the official policy of the leading men in the Republic, Oldenbarnevelt and Maurits. It would take until 1607 before the flow of pamphlets against the negotiated peace burst upon the scene. All the same, the question of 'treaty or no treaty' was not an invention dating from the years leading up to 1609 . The title of Duym's most explicit pro-war play, Een bewys dat beter is eenen goeden crijgh, dan eenen gheveynsden peys, may have been suggested by the assignment for a rhetorician contest in Leiden as early as 1596, where a refrein (the Dutch ballade) was requested with the stokregel (the Dutch refrain) Voor een beveynsde paeys, een rechte crijch te prijsen is ('More than a fake peace a just war is to be praised'). ${ }^{54}$

A closer look at the latter play, which polemically states 'Proof that a fair battle is to be preferred above a fake peace' and which is dedicated to Oldenbarnevelt, confirms the hypothesis that Duym's play, meant in support of the Grand Pensionary and the States, set out to counter inclinations to peace negotiations among the population. The play is a comedy situated in the year 1600, a memorable date because it was in that year that the battle of Nieuwpoort occurred. This hard-fought and fruitless victory of the Dutch army represents the first significant rift in the relation between Maurice, who had stated his reservations

${ }^{51}$ A copy of another play in the Ghedenck-boeck, Het innemen des Casteels van Breda, was sent to the municipality of Breda with a letter dated 6 March 1606. Poll, Over de tooneelspelen van den Leidschen rederijker Jacob Duym, 64.

52 Van Eysinga, De wording van het Twaalfjarig Bestand, pp. 76-77.

${ }^{53}$ Van Deursen, Maurits van Nassau, pp. 201-02.

54 Poll, Over de tooneelspelen van den Leidschen rederijker Jacob Duym, p. 80. 
beforehand, and Oldenbarnevelt, who had influenced the States to order the expedition. However, in his play Duym does not take his public to the battlefield, but (in an allegorical representation) to the negotiation table instead, where he assigns the hero's part to Oldenbarnevelt. Duym recalls peace offerings in $1600^{55}$ for the steadfastness of the States under the guidance of the Grand Pensionary; they were united in countering the dishonest scheme of the Spaniards which was only meant to sow discord:

$\mathrm{Al}$ het voorgaende wel aanmerckende ende ernstelijcken insiende, Edele, Erntfeste, Wijze, Voorsienighe heer heb ik goet ghevonden Comedische wijse in myn Ghedenck-Boeck te voeghen, hoe dees Landen inden jaer sestienhondert door verscheyden Ghesanten van veel Potentaten tot Vrede zijn vermaent gheweest, ende daer naer uyt Braband, dan door eenen Coopman, dan door een Advocaet zijn gheterght geweest, om haer ooren tot den vrede te keeren, altijd hopende dat soo sij den geveynsden vrede niet en wilden aengaen dat door dit gherucht van vrede tenminste onder de vereenichde Landen eenighen twist ofte tweedracht soude op staen, maer de goedighe God gaf de Moghende Heeren Staten sulck een standvastich gemoed, dat zy het Spaensch voornemen wel wetende, in plaets van vrede te maken liever onderlinghen verdraghen hebben haren Vyand te water ende te lande selver te soecken, ende haer van ghelt en volck beter versien hebben goeden Crijgh te voeren. Ende sal in dese Comedie de principaelste personagie zijn den Trouwen raed, dien de Vereenichde Provincien sullen soecken te volghen, ende alsoo uwe warachtich is den voornaemsten Raed des Lands, ende Advocaet van Holland, en heb ick desen mijnen arbeyd niemand bequamer weten toe te eijghenen, als uwe E. wiens trouwe raed hoe noodich ende profitelick hy dickmael gheweest is, ghenoech beproeft is. ${ }^{56}$

Acknowledging the aforementioned and taking it seriously, noble, honourable, wise and prudent lord, I chose to include in comic fashion in my Book of Memory, how these lands in 1600 were urged towards peace by various delegates from many rulers, and pressured thereafter from Brabant, first by a merchant, then by a lawyer, to lend their ears to peace, invariably in the hope that if these lands would not enter into the fake peace, that by this rumour of peace at least some strife or discord would rise among the united provinces. However the good Lord gave the mighty Lords of the States such a constant spirit that they, aware of the Spanish intentions, instead of making peace have rather endured to seek out their enemy at sea and on land, and provided money and manpower

${ }^{55}$ See Den Tex, Oldenbarnevelt 2: Oorlog 1588-1609, pp. 374-80.

${ }_{56}$ Jacob Duym, Een bewys dat beter is eenen goeden crijgh dan eenen gheveynsden peys (Leiden: Henrick Lodowijcxszoon van Haestens, 1606), A iij $\mathrm{r}^{\circ}-\mathrm{v}^{\circ}$. 
to fight a fair war. In this comedy the principal part will be played by the loyal Counsellor, whom the United Provinces will seek to follow, and since you are truly the prime Councillor of the Land, and Advocate of Holland, I could not have thought of a more appropriate dedicatee than Your Honour, whose loyal council, as often as it has proved necessary and profitable, was sufficiently put to the test.

Again, in the preface to 'the benevolent reader', Duym tries to elicit the goodwill of his fellow countrymen for seemingly unpopular, burdensome consequences of the politics of the war. Presenting himself as one of the people, he speaks as counsel for the defence of the official political line:

Wy bekennen wel datter veel gegeven word ende dat de lasten des oorlooghs groot zijn, maer wat ist daer moet ghegheven zijn, willen wij Goodes woord de vrijheyd des Landes ende ons eyghen rust behouden, beter ist grootelickx te gheven ende noch wat te behouwen, dan dat wy al verliesen dat wy hebben, ende in groot bedwanck der consciëntie sitten, ende weer naer galgen, raderen ende brand-staken gheleyd worden: door het geven en bevrijen wy niet alleen ons selven maer oock onse naecomelinghen, ende behouden het leven van soo veel duysent sielen die noch op verscheyden plaetsen onder het cruys sitten, ende die sy noch laten leven soo lang als sy niet heel meester en zijn, ende voor besluyt reden word hier vertoont dat wij beter de helft van al onse middelen gaven dan dat wy in de eewighe slavernije van de Spaingnaerden en haren aenhanck souden gheraken. ${ }^{57}$

We realize the many contributions that are made and the great burdens that are imposed by the war, but we have to make these sacrifices if we wish to maintain God's word, the freedom of the country and our own peace and quiet; it is better to give abundantly and to maintain something than to loose all that we have and to be conscience-stricken and led once again to gallows, wheels and stakes. Through sacrifice we free not only ourselves but also our descendants, and preserve the life of so many thousands of souls who suffer persecution and are only kept alive as long as they are not completely in control. By way of conclusion it is argued that we are better off sacrificing half our resources than living in eternal slavery to the Spaniards and their supporters.

The so-called 'people's man' Duym, ${ }^{58}$ justifying the official policy of the powers that be against certain popular sentiments, may have been less of a populist than has been presumed up to now. Even though Duym presents himself as a spokesperson by using a collective 'wy'

${ }^{57}$ Ibidem, A iv vo.

58 See n. 6. 
(we) in the above preface, he only addresses the Protestant community (approximately $20 \%$ of the population), excluding the Roman Catholics (who probably still formed the majority).

As for a performance of Het moordadich Stuck, after Duym's possible estrangement from the chamber of rhetoric 'd'Oraigne Lelie', the chamber of rhetoric 'De Witte Acoleyen' would have been the obvious place to stage the plays in the Ghedenck-boeck. No performances of any of the six plays are documented, but we must be careful to base conclusions on this ex silentio. Koppenol remarks 'as much information as we have about performances in the Leiden chambers of rhetoric in the last decade of the sixteenth century, so rare are the data for the next ten years. Quests for titles in the town archives were to no avail'..$^{59}$

\section{Het MOORDADich STUCK as a translation of AuRIacus}

A man of letters in Leiden like Duym could very well have been present at the performance of Heinsius's Auriacus. As his university education suggests and both his adaptation of Seneca's Troades and Heinsius's Auriacus confirm, Duym was sufficiently schooled in Latin to master the text he emphatically identified as the source text of Het moordadich Stuck:

Tot den Leser.

Hier sal u goetwillighe Leser voor ghestelt worden het leelijck ende moordadich stuck van Balthasar Gerards begaen aen den persoon van den Prince van Oraignen, het welck over sommighe jaeren is in den Latine ghesteld gheweest, bij den Hoogh Vermaerden Professoor ende Poet Daniel Hensio, in zijnen Auriaco, Die het selfde seer fray ghevonden ende met veel schoone Poetische spreucken verciert heeft, des en begheeren wij die sonderlinghe eer die hem toecomt gheensins te verminderen, maer alsoo onse Nederdutysche sprake soo veel wijdloopighe spreucken niet verdraghen en mach, ende dat die selvighe niet bequamelijck en konnen van woorde tot woorde over gheset worden, soo hebben wij hem ter eeren nochtans den selven Auriacum ghevolght, ende sommighe Personagien ghevoechelick naer onsen sin verandert. ${ }^{60}$

To the reader.

\footnotetext{
${ }^{59}$ Johan Koppenol, 'Jacob Duym en de Leidse rederijkers'.

${ }^{60}$ Duym, Het moordadich stuck, ed. Serrarens and Wijngaards, p. 62.
} 
Here will be presented to you, benevolent reader, the atrocious and murderous act of Balthasar Gerards, inflicted upon the person of the Prince of Orange, which has been formulated in Latin some years ago by the highly renowned professor and poet Daniel Heinsius in his Auriacus. He made the same into a very fine composition and adorned it with a lot of very beautiful poetic sayings. Hence we do not wish to detract in any way from the exceptional honour he deserves, but since our Dutch language does not tolerate so many long-winded sayings and they could not be adequately translated word for word, we nevertheless have followed, in his honour, this Auriacus and changed some characters as we judged fit and proper.'

Serrarens and Wijngaards discuss the relationship between Duym's and Heinsius's plays at great length in their edition of Het moordadich stuck. As indicated above, ${ }^{61}$ on account of the direct link Duym made between his own play and the Auriacus, they accuse him of establishing his identity 'with a false passport', hiding his true intent, presumably the wish to impose his political opinion on 'the mass of people'. In their words, Duym succeeded in 'bringing the historic event much closer to the common man'. By contrast Heinsius is accused of having 'cast his thoughts in a mould that alienated 99\% of his fellow citizens' ${ }^{62}$ Consequently, Duym is charged with untruthfulness for identifying Heinsius as his source text. Besides, Heinsius has to pay the price for sanctioning this claim in his liminal poem: 'Apparently Heinsius was still too egocentric to read Het moordadich stuck objectively in its current context. Did perhaps a certain bookishness prevent Heinsius from experiencing its topicality?'63

However, a comparison of Het moordadich stuck and Auriacus shows how Heinsius is in part followed closely, by way of direct translations or strong similarity in content, whereas elsewhere the translation or adaptation is quite free. ${ }^{64}$ The most important changes can be summed up as follows:

- The length of the drama (Auriacus 2171 verses, Het moordadich stuck 1342 verses) is reduced by $38 \%$.

\footnotetext{
${ }^{61}$ P. $1 \#$.

${ }^{62}$ Duym, Het moordadich stuck, ed. Serrarens and Wijngaards, pp. 45-50. See also Poll, Over de tooneelspelen van den Leidschen rederijker Jacob Duym, pp. 127-46 and Wijngaards, 'De zgn. Oranjestukken en hun publiek'.

${ }_{63}$ Duym, Het moordadich stuck, ed. Serrarens and Wijngaards, p. 52.

${ }^{64}$ Ibidem, pp. 14ff.
} 
- Duym adds a prologue and epilogue spoken by the Dichtstelder ('Author') which emphasize the link with the public's present. Regardless of ancient poetics the prediction of Maurits is part of the plot, breaking the unities of time and place.

- Duym reduces the epic digressions, comparisons, metaphors and sententious sayings, as he stated in his preface.

- Some personages have undergone a metamorphosis. In his preface, Duym states in the same breath that, just as he could not take over the Latin sayings in Dutch, he also needed to change some of the characters as he saw fit. However much this may seem a comparison between apples and oranges, an example clarifies the connection. In Auriacus a raging Inquisitio, carrying a torch and a cup of human blood, is accompanied by a classic threesome: the Furies, who don't deliver any lines but according to a rare stage direction of Heinsius should have an apparent ancient look and feel. ${ }^{65}$ Duym translates these ancient characters into three contemporary personifications, meant to enter the stage in costumes that appealed to the public's terror and disgust: Spaenschen Raed ('Spanish Council'), Heymelijken Haed ('Hidden Hatred') and Bloed-dorst ('Bloodthirstiness'). The first two are to be dressed like Spaniards, clothed in black trousers and a coat with a Spanish collar, Bloodthirstiness stained with blood, Inquisition herself in a Jesuit cloak and holding a rod. Later on in the play, Duym makes these three personifications return as sinnekens in the tradition of the rhetoricians. ${ }^{66}$

- The choruses have been amplified and made even more recognizable and up-to-date. Heinsius had already inserted a rather emotional chorus of Flemish refugees, saluting their new country, who were filled with melancholy and hope for the future, in a classical ode that compares a rural existence to city life. Duym expands the choir to (explicitly) 'many' Flemish refugees, divided into three social classes and dressed accordingly. Furthermore, the war veteran from Leuven adds a chorus of many refugees from Brabant, again in three social classes, commemorating the fall of Antwerp and their looted homeland.

\footnotetext{
${ }^{65}$ Following Heinsius, the Furies should look like their depictions by contemporary painters or on ancient coins, inscriptions and medallions. Heinsius, Auriacus sive Libertas saucia, ed. Bloemendal, 1, pp. 244-45.

${ }^{66} \mathrm{Cf}$. Hummelen, De sinnekens in het rederijkersdrama.
} 
Surveying the most significant changes made by Duym, the claim made by the playwright himself and sanctioned by Heinsius that Het moordadich stuck is a 'translation' of Auriacus goes a long way, given the translation practices of the time and the transfer that had to be made from one language and literary code to another. Significantly, Duym's translation of Seneca's Troades shows the same adaptation of the sententious classical style to a less verbose vernacular tradition, as well as the tendency to conform to common features of rhetorician drama by adding a prologue, epilogue and interludes spoken by the Dichtstelder. ${ }^{67}$ Likewise, in a recent paper Van Gemert, comparing related poems composed by Heinsius in a Latin and vernacular fashion, found: 'Die Gegenüberstellung beider Gedichte mag gezeigt haben, daß Heinsius bemüht war, einer offensichtlich präsupponierten Eigenständigkeit niederländischer Dichtung gegenüber der lateinischen gerecht $\mathrm{zu}$ werden. Für ihn sind beide Bereiche, gerade auch bei aller thematischen Nähe, klar getrennt. Daß hier gelehrte Anspielungen und Mythologisches einen anderen Stellenwert innehatten, liegt nahe'. ${ }^{68}$

Duym translates Heinsius's Latin Orange play, composed according to the conventions and form of ancient literarure, to the vernacular language and tradition of the rhetoricians. Both authors conform to the literary code suitable for the language and tradition in which their Orange play operates. Thus while Heinsius's Auriacus presents himself in an opening monologue in the tradition of classical freedom fighters like Brutus, Harmodius and Aristogiton, Duym's Prins van Oraignen places his struggle for independence more directly in the recent history of the Dutch revolt. Nonetheless both authors refer to the atrocities committed by the Spanish tyrant in order to justify the rebellion led by William of Orange. Consequently the conclusion of Serrarens and Wijngaards-that Heinsius's stoic, detached hero facing his Destiny with superhuman fortitude must have appealed to a smaller audience than Duym's haunted, more human, passionate and sympathetic Prince-is premature. And there is no reason whatsoever to assume that Duym would have wanted to distance himself openly from the grand theatrical gestures and bragging voice of the student

${ }^{67}$ Poll, Over de tooneelspelen van den Leidschen rederijker Jacob Duym, pp. 124-27.

${ }^{68}$ Van Gemert, 'Zum Verhältnis neulateinischer und muttersprachlicher Dichtung bei Daniel Heinsius', p. 311. 
from Leiden University playing the leading part, as Serrarens and Wijngaards picture the representation of Auriacus. ${ }^{69}$ On the contrary, both Heinsius and Duym had done the best they could, within their language and their literary system and for their own target audience, to honour the memory of William of Orange and instil in the spectators and readers patriotic sentiments and loyalty towards the Prince's heirs, Maurits and Prince Frederick Henry. Thus Heinsius, writing for a humanist public, had given the Pater patriae the stature of an ancient hero and compared his motives and his fortitude to those of classic freedom fighters. Duym however, keen to translate this ancient parallel adequately to a public accustomed to the conventions of rhetorician drama, had stripped the Prince of all these classic references and put him in a guise that was more recognizable to his audience.

\section{Conclusion}

The close interrelationship between the plays of Heinsius and Duym claimed by both playwrights cannot be disposed of as the untruthfulness of the rhetorician and snobbism of the humanist, but is confirmed on closer scrutiny. Heinsius's Auriacus was a national history drama appealing to the patriotic feelings of a humanist audience. Heinsius's wish to imitate and emulate the classical playwrights entailed the elevation of the Dutch Republic to the level of Greece and Rome. While casting national subject matter in the mould of ancient tragedy, the tribute to William of Orange as pater patriae served Heinsius well to entice the academic and political establishment and gain the necessary support for his effort to revive ancient tragedy. It was precisely in the form of the classical literary mould that the topical political moral took shape, prompting the portrayal of William of Orange as a universal stoic hero. Duym, when composing the rhetorician plays in his bellicose Book of Memory on the atrocities and treacheries committed by the Spanish enemy, recognized the degree to which a translation of Heinsius's Auriacus would suit his purpose. Transplanting Heinsius's ancient intertext, which had clearly expressed a patriotic topical message to the humanist audience of the Auriacus, Duym resorts to a literary language and visual means that are more familiar to the intended

\footnotetext{
${ }^{69}$ Duym, Het moordadich stuck, ed. Serrarens and Wijngaards, p. 30.
} 
audience of his rhetorician drama. For both authors the topical allusions are a means of connecting to their different audiences, a means of enticing them into taking an interest in their plays and inviting commitment to its subject matter. In playing to their respective audiences they play with their public's opinions.

While aiming at different audiences, composing in different coexisting literary systems, Duym's adaptation of Heinsius, 'sanctioned' in a liminal poem for Het moordadich stuck by the latter, also testifies to the interplay between the Latin and vernacular culture-interplay on the level of the authors, and even to a certain extent, as we could read in Heinsius's liminal poem, on the level of the audience: apparently, non-Latin spectators were present at the performance of the Auriacus, although Heinsius expresses his reservations as to their capacity to grasp the content of his play, pervaded as it was with an academic humanism demanding an advanced level of Latin education. It is particularly for this part of the audience that, according to our interpretation, the authorities demanded the addition of the Maurits scene at the end of the play, underlining the topical political message in a way that, if judging only by the appearance of the Stadtholder onstage, was not to be misunderstood. While the target reader of Het moordadich stuck is precisely this 'non-Latin' literate citizen, more familiar with the conventions of rhetorician drama and not required to have any knowledge of its model Auriacus, both Duym and Heinsius hasten to inform him, in the preliminary pages, of the close connection between their plays. Both authors could expect to gain literary, cultural and social capital by their affiliation: Heinsius because the example of his Auriacus had been imitated, Duym for all the reflected glory of the academic enterprise of his humanist colleague.

Which author was more successful in driving home his message? Did Duym reach a larger, less privileged audience than his humanist predecessor, as has been the general assumption up to now? Heinsius, anxious to establish his name at Leiden University, aspired to nothing less than the resuscitation of ancient tragedy. In the short term, he achieved his goal by receiving permission to stage his tribute to the university's founding father in the presence of all leading scholars of the academy and even Prince Maurits or Frederick Henry. Equally, the printed version of the play received accolades in the form of lavish declarations of sympathy from the Leiden humanists. In the long run, other men of letters followed Heinsius's innovative lead. Although the 
humanist would probably be the first to point out all the ancient poetic rules defied in the history plays written in his footsteps, the Auriacus did function as the standard-bearer of the genre of national history drama that would prosper for years to come. Duym on the other hand cannot be designated the voice of the people, who were generally weighed down by the heavy toll they paid for a long-lasting war that was losing its urgency at the beginning of the seventeenth century. From the existing evidence, it rather looks as if Duym expressed the official policy of the States led by Oldenbarnevelt, and the stadtholder Maurits. There is no proof that his play was ever performed. As far as we can see, the printed publication of the play, only affordable and readable by an elite of its own, expressed pro-war sentiments in such a blatant and one-sided fashion that it is questionable whether the voiced opinion will ever have reached a dissenting audience.

In this view, the topical allusions, adapted to the literary field in which the authors were working, are as much a means as an end. The references to contemporary politics are intrinsic to the genre of national history drama which both authors chose, recognizing its excellent possibilities for interaction with their specific audience. The Orange plays Heinsius and Duym wrote to gain their place within their literary circles gave the subgenre of the national history drama a firm footing in the Dutch Republic. Simultaneously, their written and/ or staged re-enactment of a crucial traumatic episode from recent history contributed to the self-awareness of the young Republic. Here we are in agreement with Greenblatt's notion of the complex interdependence between texts and the cultural and social contexts from which they originate and in which they circulate. Literature both reflects and shapes society. Hence literature can only be partially innovative, critical and unconventional, and partially cannot help but conform to its audience(s).

\section{EPILOGUE: LITERATURE AND THE FORMATION OF PUBLIC OPINION?}

Bloemendal and Van Dixhoorn argue that it should be no less natural for historians to use responses to social, political, religious and other issues which appeared in a literary form as well as other sources. Such literary sources should be used, not primarily as a way of lending historical work an attractive style and artistic treatment but as documents that, in their own right, serve as an integral part of such 
investigations' ${ }^{70}$ If we accept this argument then it would appear that Duym and Heinsius confront us with three potential pitfalls that, especially in combination, may be hard to circumvent: the inseparable way in which opinion is tied up with early modern literature, the process of mimesis implying a virtually untraceable transformation of reality, and the lacunae in time and research which leaves us for now with scattered and fragmented contextual information.

For a start, as we have seen, opinion is not just a recurrent feature in early-modern literature; it is inherent to the whole concept of bonae litterae. There was no literature free from value judgments. Literary form and moral content were inseparably intertwined. In the citizenship education, which was an inherent part of an early modern literary genre such as history drama, political knowledge was a prominent and even integral feature. Therefore, opinion formed literature as much as literature formed opinion. Men of letters not only (pre-eminently) employed literature to convey opinions, but equally made use of opinions to disseminate their literature. In playing with the intended audiences of their plays Heinsius and Duym played with opinion.

Furthermore, the mimetic nature of literature makes it difficult or even impossible to pinpoint the function and nature of a voiced opinion within a literary composition. The editors observe rightly that 'the opinion or opinions contained in it [...] are shaped, refined, and adapted during the creative process'. ${ }^{71}$ Opinions within literature can be a means as well as an end, and even both at the same time. Heinsius, in his dramatic representation of a patriotic message favourable to the authorities, not only conforms to his intended audience, but at the same time entices his public into accepting ancient tragedy in general and his own history play in particular. Then again, although Heinsius on his own account added the final monologue by Prince Maurits only half-heartedly, it turned out to be a major asset in the reception of the play, reinforcing a topical political message.

Consequently, we need to be well-informed as to both the context from which a literary work has originated and its reception history before we can hypothesize about its interaction with the opinions of its respective audiences. What was the social and literary status of the author, in which circles did he operate, and under the influence of

\footnotetext{
${ }^{70}$ Bloemendal and Van Dixhoorn, 'Introduction', p. 4.

${ }^{71}$ Ibidem, p. 34.
} 
which literary conventions? In what form/where/under which circumstances was a literary composition published? What were its intended and actual audiences, as far as we can induce? What kind of responses and/or imitations did it inspire?

In their introductory article, Bloemendal and Van Dixhoorn confine themselves to 'texts which were published, or written with the intention of being published, for a general public, and which aimed at informing, persuading or convincing that public'. ${ }^{72}$ However, this case study demonstrates how a considerable research gap and hasty preconceptions can blur our vision of the intended public. In-depth investigations and balanced visions of such prominent literary circuits as the academic humanist circles and the chambers of rhetoric are a prerequisite for inferences about the audiences at which a literary work aimed and, as far as we can see, actually reached. This article has shown how the playwrights Heinsius and Duym have been held captive in circular arguments that turn out to lack any solid ground. Starting from the premise that Heinsius was an elitist armchair scholar, his play, cast in a language and literary code that is hard to digest for the modern-day scholar, was considered to prove his disengagement and inability to reach an audience of consequence. By contrast, starting from the assumption that Duym must have been a popular playwright, capable of touching the hearts and minds of many people, the Dutch rhetorician was bound to have produced a successful piece of propaganda, voicing popular sentiments, with Duym's own acknowledgement of Heinsius's Auriacus as his source text merely functioning as a cover-up.

Bloemendal's and Van Dixhoorn's criticism of Habermas's polarizing concepts of early modern and modern public opinion, should be separated from the suggestion of using literature as a source for research into the formation of public opinion. Together both theses run the risk of provoking a circular argument of their own. Habermas is rightly criticized with having 'taken a rhetorical strategy used by a specific segment of the population, the eighteenth-century bourgeoisie, to be descriptive of the sociocultural reality that he then goes on to analyze'. ${ }^{73}$ However, if early modern literature is used as the sole foundation for a hypothesized early modern public opinion, the

72 Ibidem, p. 10\#.

73 Ibidem, p. 19\#. 
same danger lies in wait. Literature should not be used as conclusive testimony to support the supposition that a relevant form of public opinion did exist in early modern times. Just as the enterprise of inferring an author's or an intended audience's opinion(s) from a literary product turns out to be a hazardous one, so too the reconstruction of 'public opinion' on the insecure basis of such a complex and opaque phenomenon as early modern literature is equally unfeasible. 